\title{
Mirna Safi \\ Patterns of immigrant intermarriage in France: Intergenerational marital assimilation?
}

\section{Muster interethnischer Eheschließungen von Immigranten in Frankreich: Intergenerationale Assimilation durch Eheschließungen?}

\begin{abstract}
:
This article provides insight into immigrant intermarriage in France. It describes trends of immigrant marital behaviour between 1976 and 2000, compares intermarriage rates amongst different immigrant groups and pays particular attention to changes in marital behaviour across immigrant generations. The statistical analyses take into account individual factors and contextual effects such as the sex-ratios and sizes of the groups in question. Based on data from the Échantillon démographique permanent (Permanent Demographic Sample, EDP) of the Institut National de la Statistique et des Études Économiques (INSEE), findings point to a stable trend of marital behaviour among immigrant men and women over time, sharp differences in intermarriage rates among groups, and a significant change in the marital behaviour of secondgeneration immigrants, who intermarry much more often than their parents regardless of their origin.
\end{abstract}

Keywords: immigration, intermarriage, assimilation, second generation, contextual variables

\section{Zusammenfassung:}

Dieser Beitrag gibt Einblick in interethnische Eheschließungen in Frankreich. Es werden Trends des Heiratsverhaltens von Immigrant(inn)en in den Jahren 1976 und 2000 in Frankreich beschrieben, interethnische Eheschließungsraten bei verschiedenen Immigrantengruppen miteinander verglichen, wobei ein besonderes Augenmerk auf Veränderungen im Heiratsverhalten über die Einwanderergenerationen hinweg gerichtet wird. Bei den statistischen Analysen werden sowohl individuelle Faktoren als auch Kontexteffekte, wie z.B. das Geschlechterverhältnis und die Gruppengröße der betreffenden Gruppen, einbezogen. Auf Basis der Daten des Échantillon démographique permanent (demographische Dauerstichprobe) des Institut National de la Statistique et des Études Économiques (INSEE) deuten die Ergebnisse darauf hin, dass es einen über die Zeit stabilen Trend beim Heiratsverhalten von Männern und Frauen mit Migrationshintergrund, sehr deutliche Unterschiede in den interethnischen Eheschließungsraten zwischen den Einwanderergruppen sowie signifikante Veränderungen im Heiratsverhalten der zweiten Generation der Einwanderer gibt. Letztere gehen - unabhängig von ihrer Herkunft - sehr viel häufiger interethnische Ehen als noch ihre Eltern ein.

Schlagwörter: Immigration, interethnische Ehe, Assimilation, zweite Generation, Kontextvariablen 


\section{Introduction}

In the United States, the question of intermarriage has been a topic of main concern since the beginning of sociological migration research, with a variety of studies being performed on racial, ethnic and religious intermarriage (Barron 1951; Besanceney 1965; Kennedy 1944, 1952; Park/Burgess, 1921). Much empirical and theoretical research has been produced on this issue, investigating the relationship between intermarriage and the immigrant assimilation process. As Perlmann and Waters (2007) argue, intermarriage is important to assimilation for two main reasons: on the one hand, it reveals the degree to which "ethnic division" is declining in a society and, on the other hand, by creating generations of mixed origin, it participates in the further blurring of ethnic categories. The importance of intermarriage in the assimilation theory accounts for why American sociologists have paid much attention to its patterns and trends (Alba/Golden, 1986; Kalmijn, 1993), as well as to its effect in terms of decreasing ethnic boundaries (Pagnini/Morgan, 1990).

Unfortunately, research carried out in France on this subject is much more limited. Very rarely French studies provide information on immigrant marital behaviour or, more generally, ethnic or racial intermarriage, while publications on social homogamy are very widespread (Bozon/Héran 1987, 1988; de Singly 1987; Desrosières, 1978; Girard, 1964). This is not only because of the difficult nature of studying ethnicity in France, mainly for ideological reasons, but also because data on the ethnic origin of spouses have been very $\operatorname{rare}^{1}$ (Silberman 1992; Simon, 1998). And yet, official reports on binational marriages and new legislation on naturalization via this type of union encourage discourse about the so-called white weddings ${ }^{2}$ and, more generally, sustain negative image of immigrants.

This study aims at describing patterns of immigrant marriage in France using data that cover a long period of time (1976-2000). Particular attention is paid to the degree to which intermarriage is related to the immigrant assimilation process.

First, I analyse the evolution of immigrant marital behaviour over time. Changes in immigrant marital behaviour over the last several decades are described and confronted to the social and political representations of this issue. ${ }^{3}$

Secondly, this article studies differences in intermarriage rates among immigrant groups and provides some explanation for these differences. An important contribution lies in the analysis of the determinants of the marriage decision, which relies on both individual and contextual variables.

1 According to the French republican ideal of immigrant integration, there is no ethnic or racial differentiation in French society. This ideological position explains the scarcity of data that would make research on ethnic or racial inequalities in France possible.

2 This expression refers to binational marriages that are arranged so that the foreign spouse can acquire French nationality. In such marriages, spouses are not supposed to have any kind of conjugal life.

3 In this article, I test empirically the supposed increase in white weddings. Obviously, quantitative data cannot be used to differentiate white marriages. However, if such marriages have really increased recently, as some politicians assert, data covering a long period would allow us to detect significant changes in intermarriage patterns. This is what I did in this study. 
In my final analysis, I endeavour to measure changes in marital behaviour across generations (Min/Kim 2009). Is intergenerational assimilation occurring in France in terms of immigrant marital behaviour? Does it affect all immigrant groups equally? This article is one of the first studies to provide information on the evolution of exogamous marriages across generations of immigrants in France.

\section{Immigration and studies on intermarriage in France}

In France, almost $10 \%$ of the population is foreign born. ${ }^{4}$ This rate has remained stable over the last thirty years because of a restrictive immigration policy (Boëldieu/Borrel 2000; INSEE 2005a). While, until the 1960s immigrants used to hail mostly from Europe (especially from Spain and Italy), the second half of the $20^{\text {th }}$ century was marked by postcolonial immigration (from the African continent and South-East Asia) as well as important influx of Portuguese immigrants. This "new immigration" in the 1960s was composed mainly of seasonal and temporary workers. However, in the early seventies, immigrants began settling for good because migrating between France and their countries of origin became more and more difficult. These ever more permanent immigrants not only used family reunion procedures to bring their kin to France but also increasingly used the French marriage market to start a family. This article provides information about the latter type of union, i.e. marriages that occurred in France and involved first-generation immigrants or their descendants.

Even though France has one of the most liberal citizenship laws in the world, immigrant naturalization is a slow process; according to the 1999 census, $40 \%$ of firstgeneration immigrants are naturalized (Fougère/Safi 2009). On average, immigrants acquire French citzenship 11 years after arrival. As for second-generation immigrants, they are born French, since the French right to nationality is based on place of birth. This is why they have long been invisible in French public statistics, which used to distinguish only French citizens from non-citizens. Currently, while some important surveys have started to provide information on this population, it is still impossible to isolate secondgeneration immigrants in census data.

For a long time, the sparse information on immigrant marriage has been published in official reports analysing administrative data. Information on spouse nationality contained in the civil marriage records has been used to analyse the frequency of intermarriage in France. Researchers have continually criticized these data, pointing out that they may lead to erroneous conclusions; however, often they have been obliged to use them as well. Until very recently, the rare quantitative analyses on this subject in France have defined intermarriages as cross-national unions (Munoz-Perez/Tribalat 1984; Neyrand/Sili 1997) or as unions between a foreign-born individual and a French native (Borrel/Tavan 2004; Filhon/Varro 2005; INSEE 2005b). The scarcity of studies on intermarriage in addition to the poor quality of data used in said studies are related to the more general problem of quantitative data on immigration in France, and the fact that public statistics institutions

4 This figure may be regarded as an upper limit; it includes the highest estimations of undocumented immigrants. The official figure given by the census is around $8 \%$ (Héran 2007). 
have refused to collect detailed data on ethnic origin or, more generally, on ethnicity (Simon 1998). Important progress was made in the 1990s. For the first time in France, a specific survey on immigration was conducted in 1992; it was called Mobilité géographique et insertion sociale (MGIS). This survey was a unique source of data on ethnic origin, second-generation immigrants, and places of marriages. It led to many descriptive studies on these issues (Tribalat 1995; Munoz-Pérez/Tribalat 1996). Nevertheless, this research did not include any analysis of the evolution of intermarriage and the second-generation immigrant sample was not large enough to lead to solid findings on their marriage patterns. The weakness of intermarriage studies in France is emblematic of a more general delay in research on immigration and the assimilation process, especially from a quantitative standpoint (Safi 2008a).

Nevertheless, the study of intermarriage may be regarded as the foundation of the sociology of immigration and research on immigrant assimilation. Intermarriage is a key indicator of immigrant assimilation in a host country (Kalmijn 1998; Pagnini/Morgan 1990). Park and Burgess (1921) understood intermarriage, or what they precisely called amalgamation, as a sort of biological dimension of the assimilation process. The terminology used by these authors is very revealing of this biological connotation: crossfertilization, mulatto, mixing, blending of people, racial intermixture, etc. In his book, $A s$ similation in American life, M. Gordon (1964) developed for the first time a theoretical link between intermarriage and assimilation. Gordon spoke about the marital dimension of assimilation. Intermarriage reinforces primary contacts with the mainstream, boosting structural assimilation, thus constituting a key stage in the process. Since this pioneering work, the classical paradigm of assimilation views intermarriage as going hand in hand with assimilation: intermarriage is more likely to be observed in groups that are more assimilated culturally and economically and becomes more and more frequent across immigrant generations.

However, this relation between intermarriage and assimilation may not apply to all immigrant groups. In the United States, empirical studies influenced by multiculturalism or segmented assimilation theories have shown that some groups may keep low intermarriage rates even when experiencing ascendant economic assimilation (Glazer/Moynihan 1963; Portes/Zhou 1993). Even among old waves of immigration to the United States (i.e. immigrant waves that arrived at the turn of the $20^{\text {th }}$ century), some ethnic groups kept very low intermarriage rates: this was the case in the Jewish and Irish communities for instance. These groups are doubtlessly well integrated in the American society, especially from a socioeconomic point of view. On the other hand, there are some groups in which intermarriage is rather frequent despite the fact that their members experience lasting inferiority in the labour market. A previous study that analysed first-generation immigrant marriage showed that for some groups, patterns of intermarriage and socioeconomic assimilation do not always match in France (Safi 2008b). This study provided an empirical test of the straight-lined assimilation theory for first-generation immigrants. The present article elaborates on this first study by adding some analyses of the long-term evolution of immigrant intermarriage patterns in France. In addition, the study presented here provides information on the marital behaviour of second-generation immigrants.

Moreover, an important contribution of this study is that it takes into account the effect of contextual variables on immigrant marital behaviour. Indeed, marital choice is not 
only an individual decision, which would depend on the socio-demographic characteristics of the spouses, but also a macro-phenomenon that is affected by the structure of the population. Influenced by Blau's research on the structural determinants of marriage (Blau et al. 1982; Blau et al. 1984), Hwang, Saenz and Aguirre (1997) show that the complexity of the intermarriage issue can only be understood by using a theoretical framework that incorporates both individual and contextual variables. Even if all immigrants were to prefer endogamous marriage, assortative matching will "structurally" lead some to marriage outside the group. The size of the group and the imbalance between men and women in certain groups are the most important structural variables that may affect intermarriage. They may be regarded as proxies of the probability of encountering a spouse belonging to the same group. The general idea is that if, for structural reasons, this probability is low (small groups and/or groups with imbalanced sex-ratios), this may affect rates of outmarrying no matter how keen members of the group are on marrying someone within the group. In this research, I control for the effect of such structural variables on immigrant marital choice. ${ }^{5}$

\section{The data}

The data used is extracted from a large French longitudinal database called Echantillon démographique permanent (EDP). The EDP was created in 1967 and currently contains data from the 1968, 1975, 1982, 1990 and 1999 censuses. The EDP includes individuals born on certain days of the year: if an individual is listed in the census and meets a date of birth criterion, it is possible to follow that individual during subsequent censuses whenever he/she is listed again. The EDP is not only a compilation of censuses. It also contains information from the civil status records of EDP individuals, whenever such records are collected. This means that the main demographic events (birth, marriage, death, etc.) in the life of EDP individuals are registered in the dataset. In this study, I used data from the marriages records contracted by immigrants in France between 1976 and $2000{ }^{6}$

The EDP is valuable for the study of immigration in France for several reasons. First, it allows us to work with reasonably satisfactory numbers of immigrants from about ten groups, which is rather rare in France. Moreover, it is one of the rare French databases that make it possible to analyse second-generation immigrants. Although the census does not ask questions regarding the immigrant origins of an individual's parents, the longitudinal architecture of the EDP gives us a considerable sample of second-generation immigrants. Indeed, if an EDP individual is listed in a previous census as a "child" in a household where the head is an immigrant, it can be assumed that he or she belongs to the second generation. This method of detecting the offspring of immigrants is possible because the EDP allows us to follow individuals over censuses, and also because the census lists

5 See Safi $2008 \mathrm{~b}$ for more details on the theoretical background lying behind the control for contextual variables in the analyses of marriage behaviour.

6 In this article I used data on marriages that occurred after 1976 in order to be able to include second generation immigrants in the analysis. See the methods of detection of the second generations developed above for more details. 
all individuals in the household and gives information on their relationship to the head of the household.

In addition, regarding the specific question of immigrant marriage, the EDP contains flows rather than stocks of marriages whereas most studies on intermarriage rely on crosssectional data derived from the answers of individuals to questions about their partner's characteristics at the time of the survey. Flow data of the kind used here (i.e. data collected at the time of marriage) more accurately capture the partner's characteristics at the time of the decision to marry, some of which may change thereafter (nationality, labour market status, etc.).

Nevertheless, these data do suffer from several shortcomings, many of which are due to the fact that the EDP, or more specifically the census, was not originally designed to analyse immigration in France and thus is lacking some variables (length of stay, language fluency, etc.) that are crucial for the study of immigrant populations. As far as immigrant marriages are concerned, one specific limitation of the data lies in the fact that only weddings celebrated in France (and for which a marriage record form is collected) can be analysed. The marriages of those immigrants who decide to marry abroad are thus excluded. If these marriages have a high probability of being endogamous, which is a plausible hypothesis, this study will understate the importance of endogamous behaviour among immigrants. This limitation also biases comparison between immigrant groups, since some of them may be more inclined to marry abroad than others. Finally, the most important drawback lies in the fact that no information is available on the immigrant origin of a spouse's parents. A marriage between an immigrant and a French native will thus be regarded as exogamous even if the latter is a descendant of immigrants, a detail that the data obscures. However, since we have a sub-sample of second-generation EDP individuals, their marital behaviour is accounted for in the study. What the data cannot describe at all are marriages between spouses who are both second-generation immigrants.

\section{Patters of immigrant marriages in France}

\subsection{Overview of marriages in France}

Figure 1 summarizes the types of unions that can be detected by combining information about the spouses in EDP data. The individuals we follow across the censuses (EDP individuals) may be a French native, or first- or second-generation immigrants. Any information about their spouses is unfortunately only available in marriage records and only gives us their nationality and place of birth. Binational marriages are represented by a solid line while dotted lines are used when spouses are of the same nationality. 
Figure 1: Types of marriages observed in the EDP

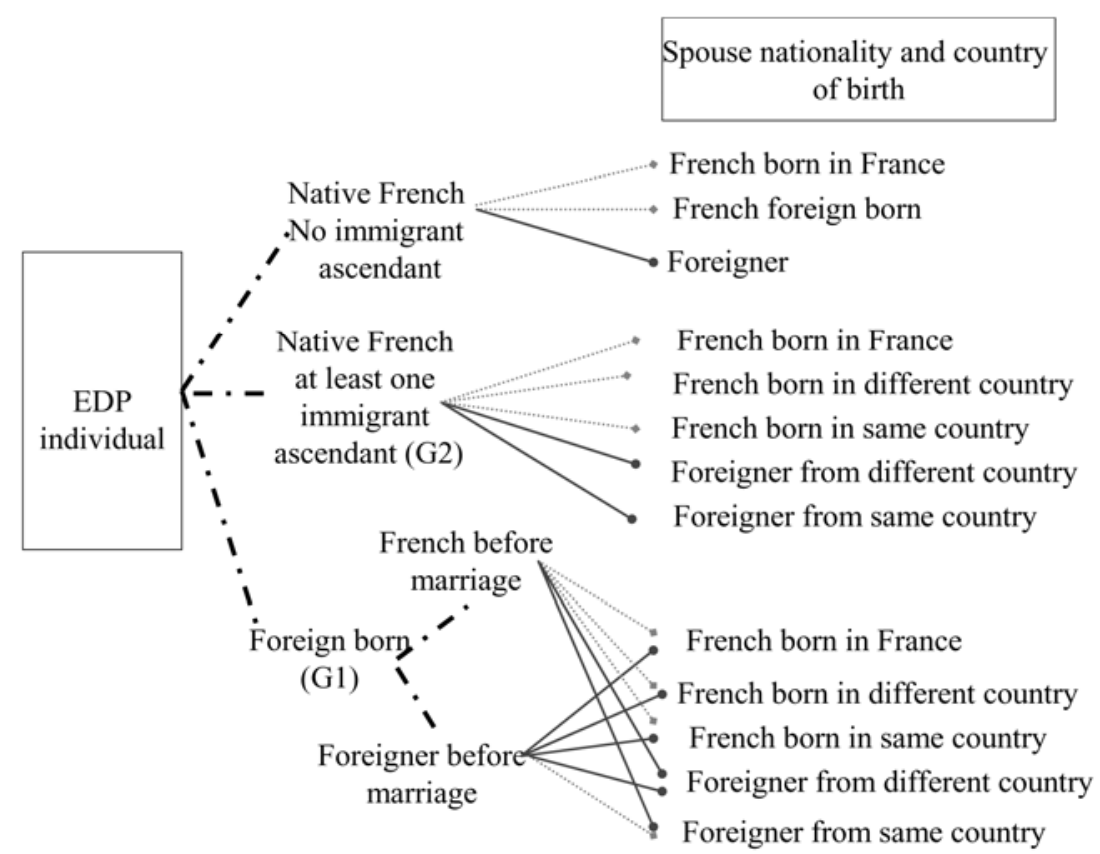

Table 1 shows that, among those marriages celebrated in France, the proportion of marriages between two French natives tends to decrease over the period. The average rate of binational marriages in 1975 was around 6\%. The overwhelming majority of these marriages were celebrated between a French native and a foreign spouse. This type of marriage continued to increase and constituted more than $9 \%$ of marriages in the $1990 \mathrm{~s}$.

Table 1: $\quad$ Types of marriages celebrated in France between 1975-2000

\begin{tabular}{lccc}
\hline Type of Marriage & $\mathbf{1 9 7 5 - 1 9 8 2}$ & $\mathbf{1 9 8 2 - 1 9 9 0}$ & $\mathbf{1 9 9 0 - 2 0 0 0}$ \\
\hline French*French & 94.51 & 92.76 & 90.37 \\
Foreigner*Foreigner & 0.33 & 0.41 & 0.50 \\
French*Foreigner & 5.16 & 6.84 & 9.13 \\
\hline
\end{tabular}

Source: EDP, INSEE; N=166.460

\subsection{Immigrant marriages}

Table 2 reports the proportion of three types of unions: marriages between spouses of the same nationality (the latter being French or non-French), marriages between two spouses of different non-French nationalities, and marriages between French natives and foreigners. The latter type is very frequent within the immigrant population. Second-generation immigrants who are themselves French citizens (because they were born on French soil) seldom choose foreign spouses $(12.5 \%)$. However, analysing marriages by only looking at 
the nationality criterion (which most official reports do) has several limitations. Indeed, it is important to take into account both the nationality and country of birth criteria (Table 3).

Table 2: Types of marriage (nationality criterion)

\begin{tabular}{llcccc}
\hline & Same nationality & $\begin{array}{c}\text { Different } \\
\text { non-French } \\
\text { nationalities }\end{array}$ & French*Foreigner & $\mathbf{N}$ \\
\hline First generation & Men & 39.9 & 5.3 & 54.8 & 3293 \\
immigrants & Women & 45.1 & 6.4 & 48.5 & 2836 \\
Second generation & Men & 93.3 & 0.0 & 6.7 & 2900 \\
Immigrants & Women & 87.5 & 0.0 & 12.5 & 3296 \\
\hline $\mathbf{N}$ & & $\mathbf{8 1 8 1}$ & $\mathbf{3 5 6}$ & $\mathbf{3 7 8 8}$ & \\
\hline
\end{tabular}

Source EDP, INSEE. Marriages celebrated by immigrants and their descendants from 1976 to 2000

When an immigrant who belongs to the first or second generation chooses a French spouse, the latter can be born in France, born abroad in a different country of origin, or born abroad in the same country of origin (Table 3). On the other hand, even marriages with a non-French spouse can be between two individuals with the same country of origin or from a different country.

Table 3: $\quad$ Spouse's nationality and country of birth

\begin{tabular}{llccccc}
\hline & & $\begin{array}{c}\text { Foreigner from } \\
\text { same country }\end{array}$ & $\begin{array}{c}\text { Foreigner from } \\
\text { different country }\end{array}$ & $\begin{array}{c}\text { French born in } \\
\text { same country }\end{array}$ & $\begin{array}{c}\text { French born in } \\
\text { different country }\end{array}$ & $\begin{array}{c}\text { French born in } \\
\text { France }\end{array}$ \\
\hline First generation & Men & 24.4 & 5.7 & 6.8 & 4.7 & 58.4 \\
immigrants & Women & 30.1 & 7.2 & 7.0 & 5.8 & 49.8 \\
Second generation & Men & 5.3 & 1.3 & 2.5 & 1.3 & 89.6 \\
immigrants & Women & 9.5 & 2.8 & 4.7 & 1.7 & 81.2
\end{tabular}

Source EDP, INSEE. Marriages celebrated by immigrants and their descendants from 1976 to 2000

These five possible choices for immigrant spouses may be merged into three types of marriage. The "most exogamous" marriage that can be observed in the EDP is one celebrated between a first- or second-generation immigrant and a French spouse born in France. This type of marriage is called exogamous French. Two other choices lead to exogamous marriages (i.e., the spouses do not belong to the same ethnic group): when the spouse is foreigner from a different country or when he/she is a French native born in a different country. Such marriages are called exogamous foreign. Finally, when a marriage involves two individuals who belong to the same ethnic group, this is called endogamous. This is the case whenever the spouse chosen by the immigrant EDP individual is a foreigner from the same country or a French native born in the same country.

Figure 2 reports the evolution of these three types of marriage for first- and secondgeneration immigrant men and women. While binational marriages clearly increased over the period (Table 1), close examination of a spouse's nationality and country of birth in Figure 2 reveals a much more stable evolution. The early 1980s were characterised by a decrease in exogamous French marriages especially for first-generation men and secondgeneration women. But the rates rose again between 1985 and 1990 for both men and 
women. Generally speaking, first-generation immigrants have a much more diverse marital behaviour than their descendants. The latter overwhelmingly marry French spouses born in France, which are the "most exogamous" marriage that our data can detect.

Figure 2: Evulution of types of immigrant marriage in France

Evolution of types of marriages for second generation immigrant men and women
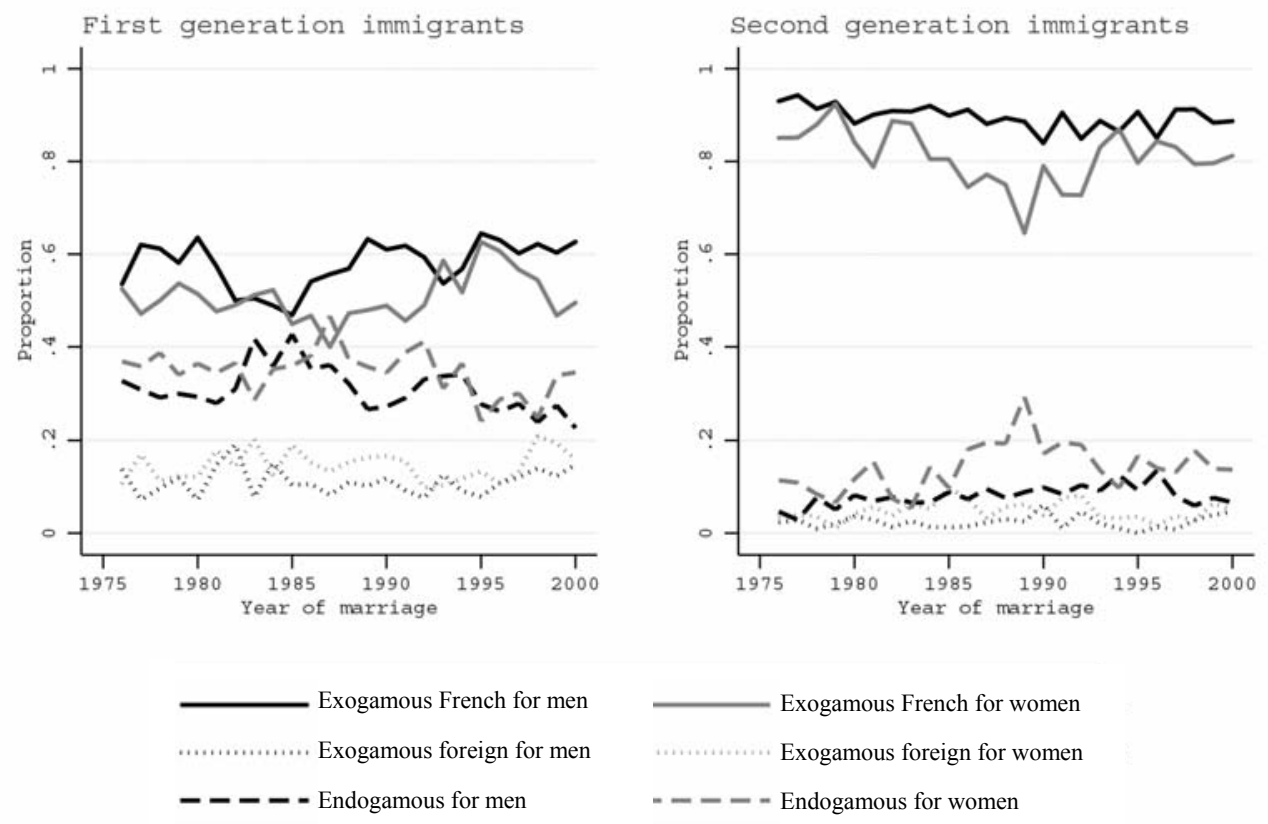

Source: EDP, INSEE

A comparison between the trend of binational marriages (Table 1), which is clearly increasing, and the trend of the different types of marriages when both nationalities and countries of birth are factored in, suggest that it is the structural transformations in French society (and not intrinsic changes in the marital behaviour of individuals) that may explain the rise of binational marriages. At least two of these structural transformations may be linked to changes in the immigrant population itself. First, an increasing number of first-generation immigrants have become naturalized citizens in the last decades. When an immigrant becomes a French citizen and subsequently marries a foreign spouse, this marriage is binational. The greater number of naturalized immigrants may thus lead statistically to a larger percentage of binational marriages without any real change occurring in the marital preferences of these immigrants. Another structural transformation is linked to the increasing number of second-generation immigrants in France over the last decades. Here again, marriages of second-generation immigrants with foreign spouses are binational. The increase in the rate of binational marriages is thus to a large extent due to the increasing proportion of second-generation immigrants rather than to a consistent change in the marital behaviour of this population. 
A considerable proportion of the so-called exogamous marriages presented in Figure 2 may be endogamous. This happens when the spouse is a first- or second-generation immigrant of the same origin, which is a distinction that cannot be made by using EDP data. However, the data report a sharp decrease in endogamous marriages between firstand second-generation immigrants, which suggests a consistent change in marital behaviour across generations. Finally, it is also clear in the data that marital choice seems to be very similar for immigrant men and women. Although the curves are very close, both first- and second-generation immigrant women do intermarry less. The last period is nevertheless characterised by an increasing convergence of the two sexes' marital behaviour.

\subsection{The determinants of immigrant marriage in France}

The following analyses only consider 18-40 year old immigrants and their offspring (5,804 men and 5,894 women). Table A.1 (in appendix) gives some information about the ethnic origins present in the sample. Indicated by their respective countries of origin, only immigrants from large national groups are considered in the following analyses: Portugal, Spain, Italy, Algeria, Morocco, Tunisia, and Turkey. Immigrants from South-East Asia (Cambodia, Laos and Vietnam) are grouped together, as are those from Sub-Saharan Africa and from Eastern and Western Europe (excluding Spain, Italy and Portugal). ${ }^{7}$

First, I estimate a multinomial logit model that distinguishes among the three types of marriages presented above. The control variables used are both individual and contextual.

\subsubsection{Individual variables}

I introduced first- and second-generation immigrants as independent variables. Information on date of arrival in France is available in the EDP only for a small number of individuals and cannot be directly used in the models. However, the longitudinal architecture of the EDP allows us to use a proxy of this variable. Indeed, when an immigrant is present in the census preceding his/her marriage (as attested by the existence of a census record), I take this as an indicator of his/her length of stay. Therefore, I distinguish between those first-generation immigrants who were present in France at the time of the census immediately preceding their marriage and those who were not listed in the previous census and are therefore assumed to be more recent arrivals. This method allows us to estimate the effect that the length of stay has on the marital behaviour of first-generation immigrants. Immigrant country of origin is also controlled for. In addition to these two variables, age at marriage and education are included in the models.

7 The sample is not representative of French immigration. It only includes those immigrants who were married in France and therefore excludes all immigrants that arrived in France already married or those who have never married. However, the sub-samples by country of origin are sizeable enough to be analysed quantitatively. 


\subsubsection{Contextual variables}

I control for the demographic imbalance between men and women within immigrant groups by introducing a variable of sex-ratio in the models below. The effect of the sexratio is assumed to work in opposite directions for men and women of the same group. When men outnumber women, men tend to marry outside the group and women marry inside it and do so independently of their intrinsic preference for endogamy. I compute the sex-ratio as the ratio between the number of men and women in each ethnic group in the EDP individual's geographical area ("département") of residence and control for this variable in the marriage equation. ${ }^{8}$

Second, I also control for immigrant group size. Indeed, many studies have shown that, independent of the preference for endogamy, members of a small group are more likely to interact with natives and these interactions increase the probability of intermarriage (Fitzpatrick/Hwang 1992; Gurak/Fitzpatrick 1982; South/Messner 1986). Thus, I include in the models a variable that measures the relative size of the immigrant group in the EDP individual's municipality of residence, calculated from the census data. ${ }^{9}$

Table 4 presents the results of a multinomial model of the three types of marriage for immigrant men and women: "endogamous marriage" (the reference in the model), "exogamous foreign marriage" and "exogamous French marriage." For men and women, the probability of entering an endogamous marriage decreases with length of stay and across generations. Length of stay seems to boost the probability of both types of exogamous marriage: marriages with a foreign spouse of different national origin or with a French spouse born in France are significantly more frequent than endogamous marriages. It is, however, interesting to note that length of stay seems to have a stronger positive effect on the probability of entering an exogamous foreign marriage, especially for men. Even if the spouse is not of the same origin, the migration experience itself may lead to a form of endogamy. As for second-generation immigrants, they differ mainly by the fact that they intermarry significantly more than their parents: their probability of entering an exogamous French marriage is much higher.

8 The geographic areas used here are French "départements" of residence. These contextual variables (sex- ratios and group size) were all computed using census data from 1975 to 1999. For example, if the observation period is between 1982 and 1990, I would compute the sex-ratios and group sizes in 1982 and control for them in the models. By doing so, I increase the variation of the computed variable: it varies among ethnic groups, across geographical areas and over the census dates.

9 In order to avoid colinearity, the geographical areas used to calculate sex-ratios and the size of the groups are different (respectively the "département" and the "commune"). Unfortunately, these statistics are available only for first-generation immigrants (since second generations are not detectable in the census). Each time we compute a contextual variable, the ethnic group is understood thus in a restrictive sense: it is composed only by first-generation immigrants. 
Table 4: Types of marriage for first- and second-generation immigrants (multinomial logit)

\begin{tabular}{|c|c|c|c|c|c|c|c|c|}
\hline & \multicolumn{4}{|c|}{ Men } & \multicolumn{4}{|c|}{ Women } \\
\hline & \multirow{2}{*}{\multicolumn{2}{|c|}{$\begin{array}{l}\text { Exogamous } \\
\text { Foreigner }\end{array}$}} & \multicolumn{2}{|c|}{ Exogamous } & \multicolumn{2}{|c|}{ Exogamous } & \multicolumn{2}{|c|}{ Exogamous } \\
\hline & & & \multicolumn{2}{|c|}{ French } & \multicolumn{2}{|c|}{ Foreigner } & \multicolumn{2}{|c|}{ French } \\
\hline & Coef & se & coef & se & coef & se & coef & se \\
\hline \multicolumn{9}{|l|}{ Immigrant generations } \\
\hline \multicolumn{9}{|l|}{$\begin{array}{l}\text { First generation not present in the } \\
\text { previous census }\end{array}$} \\
\hline $\begin{array}{l}\text { First generation present in the } \\
\text { previous census }\end{array}$ & $0,44^{* * *}$ & 0,15 & $0,16^{*}$ & 0,10 & $0,35^{* *}$ & 0,14 & $0,25^{* *}$ & 0,10 \\
\hline Second-generation immigrants & $-0,24$ & 0,19 & $1,22^{\star * *}$ & 0,11 & $-0,35^{* *}$ & 0,15 & $1,02^{* * *}$ & 0,10 \\
\hline \multicolumn{9}{|l|}{ Origin } \\
\hline \multicolumn{9}{|l|}{ Algeria } \\
\hline Sub-Saharian Africa & 0,01 & 0,26 & $-0,72^{* * *}$ & 0,16 & 0,01 & 0,22 & $-0,18$ & 0,15 \\
\hline South-East Asia & $-0,15$ & 0,27 & $-1,37^{* * *}$ & 0,18 & $-0,341$ & 0,24 & $-0,95^{\star * *}$ & 0,17 \\
\hline Western Europe & $1,07^{\star * *}$ & 0,32 & $0,70^{* * *}$ & 0,21 & $0,78^{* * *}$ & 0,27 & $1,18^{* * *}$ & 0,19 \\
\hline Eastern Europe & 0,04 & 0,40 & $0,50^{\star *}$ & 0,20 & $1,50^{* * *}$ & 0,33 & $1,98^{* * *}$ & 0,25 \\
\hline Spain & $1,52^{* * *}$ & 0,30 & $1,54^{* * *}$ & 0,20 & $0,93^{\star * *}$ & 0,25 & $1,55^{\star \star \star}$ & 0,17 \\
\hline Italy & $2,05^{\star \star *}$ & 0,31 & $2,16^{\star \star \star}$ & 0,22 & $0,74^{\star * *}$ & 0,24 & $1,70^{* * *}$ & 0,15 \\
\hline Portugal & $-0,88^{* * *}$ & 0,28 & $-0,13$ & 0,13 & $-0,79^{* * *}$ & 0,22 & 0,19 & 0,12 \\
\hline Morocco & 0,39 & 0,27 & $0,31^{*}$ & 0,16 & 0,25 & 0,20 & $-0,22$ & 0,14 \\
\hline Tunisia & $1,19^{\star * *}$ & 0,30 & $0,88^{\star * *}$ & 0,21 & $0,52^{* *}$ & 0,26 & 0,07 & 0,18 \\
\hline Turkey & $-0,40$ & 0,39 & $-0,41$ & 0.21 & $-2,14^{* * *}$ & 0,74 & $-1,49^{* * *}$ & 0,33 \\
\hline \multicolumn{9}{|l|}{ Age at marriage } \\
\hline \multicolumn{9}{|l|}{$18-20$} \\
\hline $21-25$ & 0,32 & 0,41 & 0,272 & 0,20 & 0,22 & 0,17 & $0,27^{\star * *}$ & 0,10 \\
\hline $26-30$ & 0,41 & 0,41 & $0,34^{*}$ & 0,20 & 0,21 & 0,19 & $0,45^{\star \star \star}$ & 0,12 \\
\hline $31-35$ & 0,50 & 0,42 & 0,13 & 0,22 & $0,50^{* *}$ & 0,22 & $0,28^{*}$ & 0,15 \\
\hline $36-40$ & $0,73^{*}$ & 0,44 & $-0,02$ & 0,24 & 0,36 & 0,27 & 0,11 & 0,20 \\
\hline \multicolumn{9}{|l|}{ Education } \\
\hline \multicolumn{9}{|l|}{ no diploma } \\
\hline Primary school certificate & 0,11 & 0,28 & $-0,028$ & 0,17 & 0,15 & 0,22 & $0,30^{\star \star}$ & 0,15 \\
\hline Lower secondary diploma & 0,37 & 0,30 & $0,45^{\star *}$ & 0,18 & 0,33 & 0,22 & $0,51^{* * *}$ & 0,15 \\
\hline Vocational high school & 0,05 & 0,18 & $0,50^{\star * *}$ & 0,10 & 0,11 & 0,15 & $0,47^{\star \star *}$ & 0,10 \\
\hline High school & $0,43^{\star *}$ & 0,20 & $0,35^{\star * *}$ & 0,13 & 0,11 & 0,18 & $0,51^{* * *}$ & 0,12 \\
\hline Post-secondary education & $0,51^{* * *}$ & 0,19 & $0,69^{* * *}$ & 0,12 & $0,29^{*}$ & 0,17 & $0,75^{\star * *}$ & 0,11 \\
\hline Sex ration in 'department' & $-0,19$ & 0,18 & $-0,20^{*}$ & 0,11 & $-0,31$ & 0,20 & $-0,22^{*}$ & 0,13 \\
\hline $\begin{array}{l}\text { Relative size of the group in } \\
\text { municipality }\end{array}$ & $-5,46^{*}$ & 2,02 & $-5,65^{\star \star *}$ & 1,20 & $-5,41^{\star \star *}$ & 1,66 & $-7,63^{\star * *}$ & 0,24 \\
\hline Intercept & $-1,73^{* * *}$ & 0,53 & 0,35 & 0,28 & $-0,92^{\star *}$ & 0,37 & $-0,152$ & 0,24 \\
\hline
\end{tabular}

Source EDP, INSEE

As for differences between immigrant groups, compared to Algerian men, all groups of origin seem to choose less frequently a spouse who is originally from the same country, except for South-East Asians, Africans, Turks and to a lesser extent Portuguese. Generally speaking, European immigrant men and women intermarry the most. Tunisian men also seem to have high probabilities of intermarriage. Patterns of marriage are very similar for women, apart from the fact that the vast majority of Turkish women seem to marry foreign men from Turkey. Portuguese men and women and Turkish women seem to be 
the least inclined to exogamous marriages compared to Algerians: their coefficients are negative or non-significant for both types of exogamous marriages. Their partners are most probably of the same origin.

On the other hand, intermarriage appears to be very selective in terms of human capital: the probability of an immigrant intermarrying increases sharply with education. It is clear that education level has a significant effect mostly when exogamous marriages are with native-born French spouses. The effect of the sex-ratio is very rarely significant. It seems to have a slightly negative effect on the probability that immigrant men and women will choose a French spouse born in France. While this result is counterintuitive for men, it is in line with what we expect for women: the greater a group's men-to-women ratio, the less immigrant women marry outside the group. The size of the group has a significant negative effect for men and women: the larger the group, the less exogamous marriages are celebrated by its members.

\section{Intermarriage and intergenerational assimilation}

This section focuses on the question of intergenerational differences in marital behaviour and estimate a dichotomous model of the probability of getting married to a French spouse born in France, which is the "most exogamous" type of marriage that can be observed in EDP data. Tables 5 and A.2 (appendix), and Figure 3, allow us to analyse in depth the intergenerational change in the marital behaviour of immigrants. All in all, second generations seem to have a marital behaviour that is significantly different from that of their parents.

Figure 3: Second generation coeffecients for each country (interaction effects)

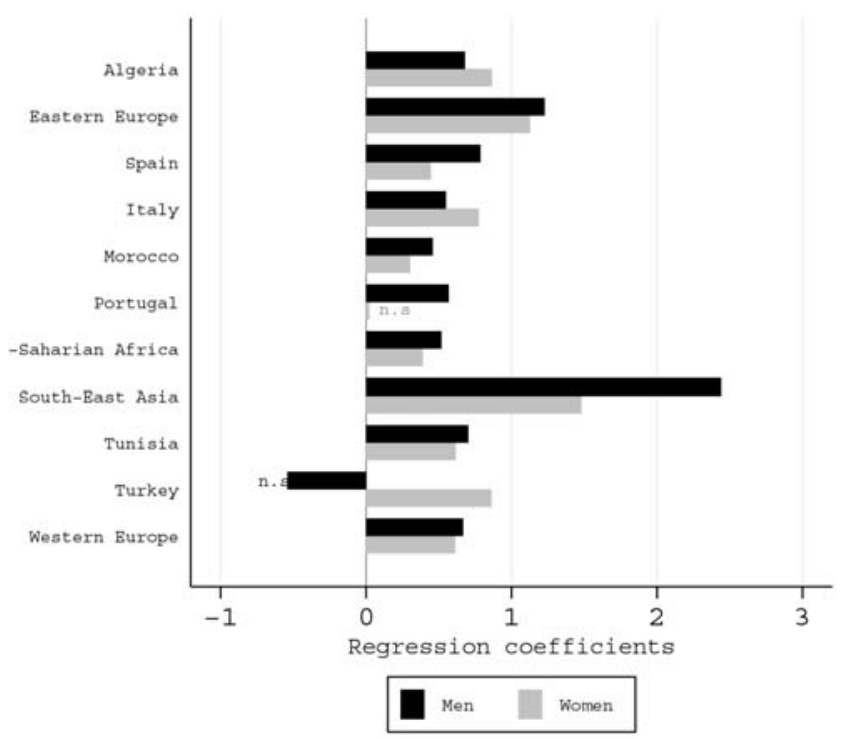

The results of the dichotomous model (Table 5) are similar to those of the multinomial one (Table 4): second generations intermarry significantly more often than first genera- 
tions. Africans, South-East Asians, Portuguese and Turks are the least likely to choose their partner from among French natives. The model in Table A.2 (appendix) introduces interaction terms between immigrant generations and countries of origin. It estimates thus an average effect of the country of origin. Figure 3 summarizes the effect of the interaction terms: for each group, the figure provides the coefficients of the second generation immigrants for men and women. The average effects are reported in Table 6 in the appendix.

According to these results, is intergenerational marital assimilation observed in all immigrant groups? While the overwhelming majority of the coefficients estimated for the interaction terms are positive and significant, two exceptions are noted: Turkish men, for whom the coefficient is negative and non-significant, and Portuguese women for whom the coefficient is positive but non-significant. These two ethnic groups are among the least exogamous. Surprisingly, endogamous behaviour is maintained much more by second-generation Turkish men than by their female counterparts. On the other hand, secondgeneration Portuguese women seem to maintain strong preferences for endogamy.

The magnitude of the coefficients reflects the speed of the transformation of the martial behaviour between first and second-generation immigrants. Asians seem to have the most extreme shift in marital behaviour between first and second generations. However, in Tables 4 and 5, our findings show that they belong to the most endogamous group. This result, apparently contradictory, best reflects how the introduction of interaction terms contributes to analyses. In Table A.2, the average effect of being an Asian immigrant is very significantly negative for men and women (this was also the case in Table 5, before any interaction terms were introduced). Therefore, Asian immigrants are on average the least exogamous immigrants. However, when the focus is on intergenerational change, their coefficients are the highest ${ }^{10}$. More generally, the coefficients of the interaction terms are the highest for those immigrants who are on average the least exogamous. On the other hand, an important result is that, with the exception of Portuguese and Turkish immigrants, no sharp differences are observed between men and women. The intergenerational shift in marital behaviour does not seem to be more significant for men.

Even if these results reflect an important change in marital behaviour between firstand second-generation immigrants, they hardly make it possible to make generalizations about immigrant intergenerational assimilation in France. Indeed, the data do not enable a more thorough examination of immigrant marriages, particularly because it is not possible to discern a spouse's immigrant ascendants in the existing data. However, apart from the size of this intergenerational change in immigrant marital behaviour and its interpretation, an important result is that this shift seems to be very similar across groups. Indeed, second generations intermarry more often for all groups and almost equally for men and women. This finding is very different from the one that would be found if we compared the economic assimilation of immigrant groups. Indeed, many studies have shown that in France, economic integration is much more significant for European immigrants and is too slow for other groups, especially those originating from African countries ${ }^{11}$. Unlike indicators

10 A Fisher test of equality of coefficients shows that estimates for Asian male and female secondgeneration immigrants are always significantly different from those of other groups. However, this result should be put into perspective, namely because of the small size of the South-East Asian sample.

11 One of the more recent figures showing the disparities between native and immigrant socioeconomic indicators are given in a publication by the Centre d'études et de recherches sur les qualifications 
of socioeconomic integration, intermarriage rates are significantly higher from one generation to another for all immigrant groups. Given that intermarriage is unanimously regarded as an indicator of immigrant cultural integration ${ }^{12}$, these results suggest that cultural integration is not a problem in France, contrary to widespread political discourse.

Table 5: Probability of marriage with a French spouse born in France for first- and second-generation immigrants (probit model)

\begin{tabular}{|c|c|c|c|c|}
\hline & \multicolumn{2}{|c|}{ Men } & \multicolumn{2}{|c|}{ Women } \\
\hline & Coef & se & se & coef \\
\hline \multicolumn{5}{|l|}{ Immigrant generations } \\
\hline \multicolumn{5}{|l|}{ First generation not present in the previous census } \\
\hline First generation present in the previous census & $0,03^{* * *}$ & 0,05 & $0,90^{*}$ & 0,05 \\
\hline Second-generation immigrants & $-0,74^{\star * *}$ & 0,05 & $0,63^{* * *}$ & 0,04 \\
\hline \multicolumn{5}{|l|}{ Origin } \\
\hline \multicolumn{5}{|l|}{ Algeria } \\
\hline Sub-Saharian Africa & $-0,43^{\star * *}$ & 0,09 & $-0,10$ & 0,07 \\
\hline South-East Asia & $-0,82^{\star * \star}$ & 0,10 & $-0,58^{* * *}$ & 0,08 \\
\hline Western Europe & $0,20^{\star * *}$ & 0,10 & $0,49^{* * *}$ & 0,08 \\
\hline Eastern Europe & $0,28^{* * *}$ & 0,10 & $0,75^{* * *}$ & $0,08^{* * *}$ \\
\hline Spain & $0,57^{* * *}$ & 0,09 & $0,70^{\star * *}$ & 0,07 \\
\hline Italy & $0,74^{* * *}$ & 0,08 & $0,85^{* * *}$ & 0,06 \\
\hline Portugal & $-0,02$ & 0,07 & $0,18^{* * *}$ & 0,06 \\
\hline Morocco & 0,13 & 0,08 & $-0,20^{* \star *}$ & 0,06 \\
\hline Tunisia & $0,30^{\star * *}$ & 0,10 & 0,01 & 0,08 \\
\hline Turkey & $-0,22$ & 0,12 & $-0,84^{* * *}$ & 0,16 \\
\hline \multicolumn{5}{|l|}{ Age at marriage } \\
\hline \multicolumn{5}{|l|}{$18-20$} \\
\hline $21-25$ & 0,13 & 0,11 & $0,13^{* * *}$ & 0,05 \\
\hline $26-30$ & 0,15 & 0,11 & 0,21 & 0,05 \\
\hline $31-35$ & 0,01 & 0,12 & 0,06 & 0,07 \\
\hline $36-40$ & $-0,15$ & 0,13 & 0,02 & 0,09 \\
\hline \multicolumn{5}{|l|}{ Education } \\
\hline \multicolumn{5}{|l|}{ no diploma } \\
\hline Primary school certificate & $-0,03$ & 0,09 & $0,15^{\star *}$ & 0,07 \\
\hline Lower secondary diploma & 0,19 & 0,09 & $0,21^{* * *}$ & 0,06 \\
\hline Vocational high school & $0,28^{* * *}$ & 0,05 & $0,28^{* * *}$ & 0,04 \\
\hline High school & $0,13^{*}$ & 0,07 & $0,27^{* * *}$ & 0,05 \\
\hline Post-secondary education & $0,30^{\star * *}$ & 0,06 & $0,40^{* * *}$ & 0,05 \\
\hline Sex ration in 'department' & $-0,10$ & 0,06 & $0,14^{* *}$ & $-0,07$ \\
\hline Relative size of the group in municipality & $-2,15^{\star * *}$ & 0,61 & $-3,37$ & 0,46 \\
\hline Intercept & 0,14 & 0,16 & $-0,21$ & 0,12 \\
\hline
\end{tabular}

*** $\mathrm{p}<0.01,{ }^{* *} \mathrm{p}<0.05,{ }^{*} \mathrm{p}<0.1$

Source EDP, INSEE

(CEREQ) on young people who recently left the educational system (Joseph et al. 2008). The data show very high penalties in terms of unemployment and wages for African second-generation immigrants (see particularly pp. 7-8).

12 According to the classical work of Gordon (1964), intermarriage (or marital assimilation) is the final stage of the assimilation process. It is a sign that cultural assimilation (adaptation of the home country's ways so that they fit with the culture of the host country) has been achieved. 


\section{Conclusion}

This article sheds light on patterns of immigrant marriage in France by using particularly effective data. Firstly, the EDP data cover a long period of time, thus making it possible to analyse trends and evolutions. Secondly, this dataset contains a sizeable sample of immigrants belonging to a variety of groups of origin, thus making it possible to compare their propensities for intermarriage. Thirdly, the EDP is one of the very rare public statistics datasets in France that enable the comparison of first- and second-generation immigrant intermarriage. In this article, we take advantage of these positive attributes.

Studying the evolution of immigrant marital behaviour is very instructive: it is the only way to know whether immigrants tend to intermarry more in later generations. While social representations emphasize increased binational marriages in France, suspecting many of them to be "fake", this article shows that the marital behaviour of first- and second-generation immigrants was rather stable over a thirty-year period, when both nationality and country of birth criteria were taken into account. The increasing number of naturalized immigrants and second-generation immigrants probably lurks in the rise in binational marriages. According to this result, and as far as quantitative data can tell, there is no empirical evidence of an increase in "white weddings" in France.

Analysing the determinants of immigrant marriage shows that differences between countries of origin remain very strong. European immigrants mostly enter exogamous marriages while the non-Europeans maintain strong preferences for endogamy even when they get married in France. However, some exceptions exist: Tunisian men seem to have intermarriage rates very close to those of Europeans, and Portuguese are more similar to Algerians than to Italians. These differences between immigrant groups are significant despite the control for some contextual variables that account for structural determinants of intermarriage.

However, second generation immigrants' marital behaviour seems much more homogeneous than the one of their parents. Indeed, an intergenerational change seems to be very strong for all immigrant groups, perhaps constituting the fastest changing component of immigrant assimilation in France (especially compared to socioeconomic assimilation). For all countries of origin, second-generation immigrants choose French spouses born in France much more often than their parents did. Turkish and Portuguese immigrants are the only groups for which this result is not valid.

Does this final finding prove that intermarriage is a sort of path to immigrant assimilation in France? Several limitations of this study make answering this question impossible. These limitations are above all related to the quality of the data. Although the EDP is one of the best databases for allowing this kind of study in France, it cannot be used to support definitive conclusions on immigrant assimilation. First, the data do not account for marriages celebrated by immigrants abroad, which leads to an underestimation of endogamous marriages, especially for first-generation immigrants. Second, the EDP does not allow us to detect whether or not the French spouse born in France is a secondgeneration immigrant. A sizable share of exogamous marriages entered into by secondgeneration immigrants may therefore be endogamous. Were the distribution of endogamous marriages by second-generation immigrants to differ sharply across groups, this may considerably bias the results of the study. 
Despite these numerous drawbacks, the findings presented in this article reflect the fact that the social interactions between the second-generations and French natives are very significant, leading almost "mechanically" to more exogamous marriages within this population. Intermarriage may therefore be considered more a "natural outcome" of increasing social contact between immigrants and natives than a sign of successful intergenerational assimilation.

\section{References}

Alba, R. \& Golden, R. (1986). Patterns of ethnic marriage in the United States. Social Forces, 65, pp. 202-223.

Barron, M. (1951). Research on intermarriage: a survey of accomplishments and prospects. The American Journal of Sociology, 57, pp. 249-255.

Besanceney, P. (1965). On reporting rates of intermarriage. The American Journal of Sociology, 70, pp. 717-721.

Blau, P., Beeker, C. \& Fitzpatrick, K. (1984). Intersecting social affiliations and intermarriage. Social Forces, 62, pp. 585-606.

Blau, P., Blum, T. \& Schwartz, J. (1982). Heterogeneity and intermarriage. American Sociological Review, 47, pp. 45-62.

Boëldieu, J. \& Borrel, C. (2000). La proportion d'immigrés est stable depuis 25 ans. INSEE Première, $N^{o}$ 748, Novembre 2000.

Borrel, C. \& Tavan, C. (2004). La vie familiale des immigrés. France, Portrait Social, Édition 20032004, pp. 109-124.

Bozon, F. \& Héran, F. (1987). La découverte du conjoint : I. Évolution et morphologie des scènes de rencontre. Population, 42, pp. 943-985.

Bozon, F. \& Héran, F. (1988). La découverte du conjoint : II. Les scènes de rencontre dans l'espace social. Population, 43, pp. 121-150.

de Singly, F. (1987). Théorie critique de l'homogamie. L'année sociologique, 37, pp.181-205.

Desrosières, E. (1978). Marché matrimonial et structure des classes sociales. Actes de la Recherche en Sciences Sociales, 20-21, pp. 97-107.

Filhon, A. \& Varro, G. (2005).. In: C. Lefèvre \& A. Filhon, A. (Eds), Histoires de familles histoires familiales. Paris: INED, pp. 483-501.

Fitzpatrick, K. \& Hwang, S. (1992). The effects of community structure on opportunities for interracial contact: extending Blau's macrostructural theory. Sociologicial Quarterly, 33, pp. 51-61.

Fougère, D. \& Safi, M. (2009). Naturalization and employment of immigrants in France (1968-1999). International Journal of Manpower, 30, pp. 83-96.

Girard, A. (1964). Le choix du conjoint, Paris: Presses Universitaires de France.

Glazer, N. \& Moynihan, D. (1963). Beyond the melting pot: The Negroes, Puerto Ricans, Jews, Italians and Irish of New York City. Cambridge: MIT Press.

Gordon, M. M. (1964). Assimilation in American life: The role of race, religion, and national origins. New York: Oxford University Press.

Gurak, D. \& Fitzpatrick, J. (1982). Intermarriage among Hispanic ethnic groups in New York City. The American Journal of Sociology, 87, pp. 921-934.

Héran, F. (2007). Le temps des immigrés, Essai sur le destin de la population française. Paris: Seuil.

INSEE [Institut National de la Statistique et des Études Économiques] (2005a). Les immigrés en France. Paris: Insee-Références.

INSEE [Institut National de la Statistique et des Études Économiques] (2005b). Mixité des couples. Les immigrés en France: INSEE. Paris: INSEE.

Joseph, O., Lopez, A. \& Ryk, F. (2008). Génération 2004: des jeunes pénalisés par la conjoncture. Bref, Cereq, $n^{\circ} 248$. 
Kalmijn, M. (1993). Trends in black/white intermarriage. Social Forces, 72, pp. 119-146.

Kalmijn, M. (1998). Intermarriage and homogamy: causes, patterns, trends. Annual Review of Sociology, 24 , pp. $395-421$.

Kennedy, R. J. R. (1944). Single or triple melting-pot? Intermarriage trends in New Haven, 1870-1940. The American Journal of Sociology, 49, pp. 331-339.

Kennedy, R. J. R. (1952). Single or triple melting-pot? Intermarriage in New Haven, 1870-1950. The American Journal of Sociology, 58, pp. 56-59.

Min, P. G. \& Kim, C. (2009). Patterns of intermarriages and cross-generational in-marriages among native-born Asian Americans. International Migration Review, 43, pp. 447-470.

Munoz-Perez, F. \& Tribalat, M. (1984). Mariages d'étrangers et mariages mixtes en France: évolution depuis la Première Guerre. Population, 39, pp. 427-462.

Neyrand, G. \& Sili, M. R. (1997). Les couples mixtes dans la France contemporaine. Mariage, acquisition de la nationalité française et divorce. Population, 52, pp. 571-606.

Pagnini, D. \& Morgan, S. (1990). Intermarriage and social distance among U.S. immigrants at the turn of the century. The American Journal of Sociology, 96, pp. 405-432.

Park, R. E.\& Burgess, E. W. (1921). Introduction to the science of sociology. Chicago: University of Chicago Press.

Perlmann, J. \& Waters, M. C. (2007). Intermarriage and multiple identities. In: M. C. Waters \& R. Ueda (Eds), The new Americans. A guide to immigration since 1965. Cambridge, MA \& London: Harvard University Press, p. 110-123.

Portes, A. \& Zhou, M. (1993). The new second generation: Segmented assimilation and its variants. Annals of the American Academy of Political and Social Science, 530, pp. 74-96.

Safi, M. (2008a). The immigrant integration process in France: Inequalities and segmentation. Revue française de sociologie, pp. 3-44.

Safi, M. (2008b). Intermarriage and assimilation: Disparities in levels of exogamy among immigrants in France. Population-E, 63, pp. 239-268.

Silberman, R. (1992). French immigration statistics. In; D. L. Horowitz, \& G. Noiriel (Eds), Immigrants in two democracies: French and American experience: New York: New York University Press, pp. 112-123,

Simon, P. (1998). Nationalité et origine dans la statistique française. Population, 53, pp. 541-567.

South, S. \& Messner, S. (1986). Structural determinants of intergroup association: interracial marriage and crime. The American Journal of Sociology, 91, pp. 1409-1430.

Submitted on/Eingereicht am: 12.10.2009

Accepted on/Angenommen am: 27.01.2010

Address of the author/Anschrift der Autorin:

\section{Dr. Mirna Safi}

Science Po, OSC

27, Rue Saint-Guillaume

F-75337 Paris Cedex 07

France

E-mail: mirna.safi@sciences-po.fr 


\section{Appendix}

Table A 1: The composition of the sample

\begin{tabular}{|c|c|c|c|c|}
\hline \multirow[b]{2}{*}{ Origin } & \multirow{2}{*}{$\begin{array}{c}\text { Men } \\
\mathbf{N}\end{array}$} & \multicolumn{3}{|c|}{ Women } \\
\hline & & $\%$ & $\mathbf{N}$ & $\%$ \\
\hline West-Europe & 465 & 8.0 & 540 & 9.2 \\
\hline East-Europe & 399 & 6.9 & 442 & 7.5 \\
\hline Spain & 665 & 11.5 & 705 & 12.0 \\
\hline Italy & 990 & 17.1 & 975 & 16.5 \\
\hline Portugal & 840 & 14.5 & 825 & 14.0 \\
\hline Subsaharian Africa & 305 & 5.3 & 325 & 5.5 \\
\hline South-East Asia & 274 & 4.7 & 282 & 4.8 \\
\hline Algeria & 989 & 17.0 & 1050 & 17.8 \\
\hline Morocco & 428 & 7.4 & 438 & 7.4 \\
\hline Tunisia & 309 & 5.3 & 246 & 4.2 \\
\hline Turkey & 140 & 2.4 & 66 & 1.1 \\
\hline Total First generation & 2931 & 50.5 & 2633 & 44.7 \\
\hline Total Second generation & 2873 & 49.5 & 3261 & 55.3 \\
\hline Total & 5804 & 100.0 & 5894 & 100.0 \\
\hline
\end{tabular}

Source EDP. INSEE 
Table A.2: Probability of marriage with a French spouse born in France for first- and second-generation immigrants (probit model with interaction effects)

\begin{tabular}{|c|c|c|c|c|}
\hline & \multicolumn{2}{|c|}{ Men } & \multicolumn{2}{|c|}{ Women } \\
\hline & Coef & se & se & coef \\
\hline \multicolumn{5}{|l|}{ Origin (average effect) } \\
\hline \multicolumn{5}{|l|}{ Algeria } \\
\hline Africa & $-0,45^{\star \star *}$ & 0,08 & 0,10 & 0,09 \\
\hline South-East Asia & $-1,11^{\star * *}$ & 0,09 & $-0,51^{* * *}$ & 0,10 \\
\hline Western Europe & $0,12^{\star * *}$ & 0,11 & $0,66^{\star * *}$ & 0,10 \\
\hline Eastern Europe & $-0,15$ & 0,13 & $0,62^{* * *}$ & 0,12 \\
\hline Spain & $0,52^{\star * *}$ & 0,10 & $0,98^{* * *}$ & 0,10 \\
\hline Italy & $0,83^{\star * \star}$ & 0,10 & $0,89^{* * *}$ & 0,11 \\
\hline Portugal & $-0,03$ & 0,07 & $0,54^{* * *}$ & 0,08 \\
\hline Morocco & 0,13 & 0,08 & 0,11 & 0,09 \\
\hline Tunisia & $0,31^{* * *}$ & 0,10 & 0,18 & 0,13 \\
\hline Turkey & $-0,20^{*}$ & 0,10 & $-0,72^{* * *}$ & 0,18 \\
\hline \multicolumn{5}{|l|}{ Origin* generation (interaction effect) } \\
\hline Algeria* $2 d$ generation & $0,67^{\star * *}$ & 0,07 & $0,86^{\star * *}$ & 0,07 \\
\hline Sub-Saharian Africa*2d generation & $0,51^{\star * *}$ & 0,17 & $0,40^{* * *}$ & 0,14 \\
\hline South-East Asia*2d generation & $2,43^{\star * *}$ & 0,33 & $1,47^{* * *}$ & 0,21 \\
\hline Western Europe ${ }^{\star} 2 d$ generation & $0,66^{\star * *}$ & 0,12 & $0,62^{* * *}$ & 0,11 \\
\hline Eastern Europe ${ }^{\star} 2 d$ generation & $1.22^{\star \star *}$ & 0,15 & $1,16^{* * *}$ & 0,14 \\
\hline Spain*2d generation & $0,78^{\star * *}$ & 0,11 & $0,46^{* * *}$ & 0,10 \\
\hline Italy*2d generation & $0,55^{\star * *}$ & 0,11 & $0,78^{* * *}$ & 0,10 \\
\hline Portugal $^{*} 2 \mathrm{~d}$ generation & $0,57^{\star \star \star}$ & 0,09 & 0,03 & 0,08 \\
\hline Morocco*2d generation & $0,45^{\star * *}$ & 0,12 & $0,30^{* * *}$ & 0,10 \\
\hline Tunisia*2d generation & $0,70^{\star * *}$ & 0,15 & $0,59^{* * *}$ & 0,15 \\
\hline Turkey²d generation & $-0,55$ & 0,39 & $0,88^{* *}$ & 0,39 \\
\hline \multicolumn{5}{|l|}{ Age at marriage } \\
\hline \multicolumn{5}{|l|}{$18-20$} \\
\hline $21-25$ & 0,063 & 0,09 & $0,13^{* * *}$ & 0,05 \\
\hline $26-30$ & 0,05 & 0,10 & $0,20^{* * *}$ & 0,05 \\
\hline $31-35$ & 0,11 & 0,10 & 0,08 & 0,07 \\
\hline $36-40$ & $-0,27$ & 0,11 & 0,02 & 0,09 \\
\hline \multicolumn{5}{|l|}{ Education } \\
\hline \multicolumn{5}{|l|}{ no diploma } \\
\hline Primary school certificate & $-0,05$ & 0,08 & $0,14^{* *}$ & 0,07 \\
\hline Lower secondary diploma & $0,17^{\star *}$ & 0,07 & $0,22^{* * *}$ & 0,06 \\
\hline Vocational high school & $0,27^{\star \star \star}$ & 0,04 & $0,29^{* * *}$ & 0,04 \\
\hline High school & $0,16^{* * *}$ & 0,06 & $0,30^{* * *}$ & 0,05 \\
\hline Post-secondary education & $0,30^{\star * *}$ & 0,05 & $0,42^{* * *}$ & 0,05 \\
\hline Sex ration in 'department' & $-0,10^{*}$ & 0,06 & $0,11^{*}$ & 0,07 \\
\hline Relative size of the group in municipality & $-2,53^{* * *}$ & 0,52 & $-3,46^{* * *}$ & 0,47 \\
\hline Intercept & $0,29^{* *}$ & 0,14 & $-0,39^{\star * *}$ & 0,12 \\
\hline
\end{tabular}

$* * * \mathrm{p}<0.01, * * \mathrm{p}<0.05, * \mathrm{p}<0.1$

Source EDP, INSEE 